\title{
Balkan Piyasalarını Hedef Alan Doğal Gaz Boru Hattı Projeleri Arasında Rekabet: NABUCCO-Güney Akım ve Trans-Adriyatik Boru Hattı (TAP) Projeleri Örneği
}

\author{
Volkan ÖZDEMIR \\ ozdemir@eppen.org
}

\section{Competition between Natural Gas Pipeline Projects That Target Balkan Markets: In the Case of NABUCCO-South Stream and Trans- Adriatic Pipeline (TAP) Projects}

\begin{abstract}
In this article it is argued that historical rivalry for the dominance over Balkan region between Austrian-Russian and Ottoman Empires has been reproduced in the form of geopolitics of natural gas pipelines in the 21st century. In order to transport Azeri gas to South East Europe a harsh competition has been observed between some pipeline projects which have been developed by different actors that seek to pursue their own strategic interests. After a choice by Shah Deniz Consortium, TANAP and TAP projects have become the winners of this competition. During the process of three-lateral energy diplomacy between EU-Russia and Turkey, while Russia and Turkey have been taking into account each other's positions, at the end of the day the loser had become NABUCCO Project which is supported by Austria and other central EU members.

Keywords

Natural Gas, Geopolitics of Pipelines, EU, Russia, Turkey.

JEL Classification Codes$$
\text { Q34, Q35, Q41, Q48. }
$$

Özet

$\mathrm{Bu}$ makalede Balkan ülkeleri söz konusu olduğunda tarihi olarak Avusturya-Rusya-Osmanlı İmparatorlukları arasındaki güç mücadelesinin 21. yüzyılda doğal gaz boru hatları jeopolitiği üzerinden yeniden ortaya çıktığı iddia edilmektedir. Stratejik çıkarları farklı olan çeşitli aktörler tarafından geliştirilen bir takım boru hattı projeleri Azeri gazını Güney Doğu Avrupa (Balkan) ülkelerine ulaştırmak için birbirleriyle sert bir rekabete girişmişlerdir. Bu yarıştan, Şah Deniz Konsorsiyumu'nca yapılan tercih sonrası TANAP ve TAP doğal gaz boru hattı projeleri galip çıkmıştır. AB-Rusya-Türkiye arasındaki üç taraflı enerji diplomasisi sürecinde Rusya ve Türkiye birbirlerinin konumlarına paralel hareket ederken, söz konusu rekabette kaybeden NABUCCO projesi ile Avusturya özelinde merkezi AB ülkeleri olmuştur.
\end{abstract}




\section{Acknowledgement}

This article is derived from the $\mathrm{PhD}$ thesis of the author, which is "Economic Aspects of Turkish-Russian Relations in Gas Sector".

\section{Beyan}

$\mathrm{Bu}$ çalışma yazarın "Gaz Sektöründe Türkiye-Rusya İlişkilerinin İktisadi Boyutları" konulu yayımlanmamış doktora tezinden üretilmiştir. 


\section{Giriş}

Hidrokarbonların uluslararası ticareti söz konusu olduğunda ağırlıklı olarak denizler üzerinden tankerlerle taşınan petrolün aksine, doğal gaz hala \%68'lik gibi büyük bir oranla karasal alanda boru hatlarıyla piyasalara ulaştırılmaktadır (BP, 2013: 29). Bu nedenle, doğal gaz değer zincirinin önemli bir halkasını oluşturan taşımacılıkta, boru hattı projeleri önem kazanmaktadır. Türkiye'nin de içinde yer aldığı Avrupa gaz piyasasında ise doğal gaz boru hatlarının bu değer zincirindeki ağırlığı dünyadaki diğer bölgesel piyasalara nazaran daha fazla olup, Asya-Pasifik ve Amerika doğal gaz piyasalarından farklı olarak sınır ötesi boru hatları Avrupa'da enerji güvenliğinin en önemli bileşeni olarak değerlendirilmektedir. Avrupa gaz piyasasında, Rusya başta olmak üzere Hazar havzası ülkelerinin tedarikçi/ihracatçı ve bunların batısında yer alan çeşitli Avrupa ülkelerinin ise tüketici/ithalatçı olduğu gerçeği doğal gaz kaynaklarının üçüncü ülkelere aktarılması için geliştirilen uluslararası transit projeleri arasındaki rekabetin doğasını da belirlemektedir.

Uluslararası petrol ve gaz piyasalarında çok uluslu petrol şirketlerin yanı sıra transit konumu nedeniyle Türkiye'nin, büyük tüketim rakamları sebebiyle AB'nin ve en büyük gaz ihracatçısı olması hasebiyle de Rusya'nın kaynakların bölgeye ulaştırılması konusunda hayati çıkarları bulunmaktadır. Tarafların çıkarları ve bu doğrultuda geliştirdikleri politikalar ile ülkeler arasındaki ilişkilerin seyri Balkan coğrafyası odaklı uluslararası doğal gaz transit projelerindeki rekabetin gelişiminde belirleyici bir rol oynamaktadır. Çünkü birbiriyle rekabet halinde olan boru hattı projelerinin salt iktisadi bir işleyiş mekanizması nedeniyle bölgeyi hedeflemediği, boru hatlarının üzerinden geçtiği ülkelerde siyasi etkiler bırakacak daha geniş bir stratejik amaca da hizmet edecek bir araç olduğu açıktır. Bölge ülkelerindeki enerji altyapısının kontrolünü elinde tutacak olan aktörlerin yine bölge ülkeleri üzerinde ciddi bir siyasi etkinlik alanı kurmak istemesi de bu rekabetin doğasını kızıştıran en önemli unsurdur. Zira boru hatları siyasetinde güzergâh seçimi, meselenin en önemli boyutunu oluşturmaktadır. Çünkü boru hatları jeopolitiğini önemli kılan temel kural, kaynak akışını kontrol edenin aslında enerji kaynağının kendisini de kontrol ederek, transit güzergâhları aracılığıyla siyasi nüfuz alanını da arttırmasıdır (Xuetang, 2006: 126).

\section{Bölgenin Gaz Talep Görünümü ve İlgili Aktörlerin Boru Hattı Siyasetini Belirleyen Temel Unsurlar}

AB ülkeleriyle Türkiye ve Rusya arasında kalan Balkanlar üzerinde yaşanan siyasi nüfuz mücadelesinin başlıca unsurunun bölge pazarını hedef alan doğal gaz boru hatları projeleri olması, bu bölgenin tüketim/talep dinamiklerini incelemeyi zorunlu kılmaktadır. Bahsi geçen bölge, coğrafi olarak Avrupa'nın göbeğinde yer almakta ve iktisadi işleyiş mantığı açısından dünya gaz piyasalarındaki en büyük üç tüketim bölgesinden bir olan Avrupa gaz piyasası içerisinde bulunmaktadır. Avrupa gaz piyasası ise gerek hukuki düzenlemeler, gerekse piyasa mekanizmasının işlerliği açısından kendi içerisinde farklılıklar barındıran bir görünümdedir. Bu bağlamda, Avrupa gaz piyasasını $A B$ ve $A B$ dışı Avrupa ülkeleri olmak üzere kabaca ikiye ayırmak mümkündür. Belirli bir 
doygunluğa ulaşmış ve tüketim yaygınlığı açısından 'olgun' kabul edilen $\mathrm{AB}$ ülkelerindeki gaz piyasalarının aksine, başta eski Yugoslavya ülkeleri olmak üzere Balkan (Güney Doğu Avrupa) ülkelerinin gaz piyasa yapısı farklı tüketim dinamiklerine sahiptir. Merkezi AB ülkelerinin aksine, Balkan ülkelerindeki gaz piyasaları gelişimini henüz tamamlamamışıtır ve yüksek talep potansiyelini de bünyelerinde barındırmaktadır. Balkan ülkelerindeki enerji kaynaklarına olan talebin hızlı bir şekilde arttığı düşünüldüğünde, bu ülkelerin enerji jeopolitiğinden bağımsız olarak, ekonomik karlılık açısından da uluslararası petrol şirketleri nezdinde giderek ilgi çekici bir hedef pazar haline dönüştükleri de ileri sürülebilir. Zira bu durum söz konusu bölgeye ulaşmak için birçok gaz boru hatt1 projesinin tasarlanmasında önemli bir faktör olmuştur.

Avrupa, Kuzey Amerika ve Asya piyasalarından sonra dünyada tüketim miktarı olarak üçüncü en büyük doğal gaz piyasasına sahiptir. Dünya toplam gaz tüketiminin \%16'sını oluşturan AB, Türkiye ve Balkan ülkelerini kapsayan Avrupa gaz piyasasında 2012 senesi içinde 539 milyar metre küp (mmk) doğal gaz tüketilmiştir (International Gas Union, 2013: 16). Türkiye hariç diğer tüm Güney Doğu Avrupa ülkelerinin senelik gaz tüketimi ise 30 mmk.e ulaşmaktadır (Stambolis, 2012). Bunun yanında, Avrupa Komisyonu'nun geçmiş tahminleri doğrultusunda 2000 yılında 376 milyon ton petrol eşdeğeri olan salt $\mathrm{AB}$ gaz talebi ise 2030 'da 600 milyon tona yaklaşacak ve iç üretimin düşmesiyle birlikte $A B$ 'nin doğal gazda diş kaynaklara bağımlılığı 2030 yılına kadar 2000 senesindeki \%50 rakamından \%80'lere çıkacaktı (Seliverstov, 2006: 203-212). Ancak AB ülkeleri için yapılan bu tahminler 2008 Ekonomik krizinden fazlasıyla etkilenen $\mathrm{AB}$ ekonomilerinin durumu düşünüldüğünde gerçekliliğini yitirmeye başlamıştır. AB ülkeleri gaz talebi kriz öncesinde doyuma ulaşmış, kriz sonrasında düşüşler yaşamış ve en önemlisi gelecekte de talebin artışı konusunda umut vaat etmemektedir. Buna mukabil, sadece Hirvatistan, Sirbistan, Bosna-Hersek, Karadağ, Makedonya, Kosova ve Arnavutluk'u kapsayan Batı Balkanlarda gaz talebinin 2030 yılında bugünkü miktarını ikiye katlayarak 21 mmk.ü aşması öngörülmektedir (Pesut, 2013). Burada yukarıda sayılan ilk üç ülke hariç diğerlerinde doğal gazın ya çok düşük miktarda kullanıldığı ya da henüz kullanımda olmayıp, gaz altyapısının yeni kurulmakta olduğunun altı çizilmelidir. Gaz kullanımı olan ülkelerden ise Hırvatistan, Sırbistan ve Bosna-Hersek üçlüsünün ana tedarikçisi Rusya'dır. Batı Balkan ülkelerinden sadece Hırvatistan toplam gaz tüketiminin \%60'ını karşılayan bir üretime sahiptir (CSIS Report, 2010) Ayrıca bu ülke Adriyatik kıyılarındaki Krk şehrinde inşa edilen LNG terminali sayesinde ENI firmasından Cezayir menşeli gaz almakta ve kaynak çeşitliliğine gitmeyi başarmaktadır. Rusya, Güney Akım projesine bu ülkeyi dâhil etmek isteyerek aslında kaybettiği pazar payını geri almayı hedeflemektedir. Hırvatistan'dan sonra GAZPROM, Bosna içindeki Sırp Cumhuriyeti, Karadağ ve Makedonya'yla da Güney Akım'ın bu ülkelere uzatılması projesini gündeme almış ve ikili anlaşmalara hız vermiştir. En son olarak 20113 yılında Macadonia Energy resources ve GAZPROM şirketleri arasında eşit ortaklıkla kurulacak şirket Güney Akım'ın bu ülkeye uzanan ilave hattının işletiminden sorumlu olacaktır (B92, 2013) Mevcut konumunu pekiştirmek isteyen GAZPROM, yıllar önce yaptığı bir çalışmada kendisine Balkanlarda üst olarak seçtiği ve iletim hatlarına sahip olduğu Sırbistan üzerinden karşılayabileceği Bosna-Hersek, Makedonya, Karadağ, Arnavutluk ve Hırvatistan için sırasıyla 1.5, 1, 1, 0.5 ve 0.5 olmak üzere toplam 4.5 mmk.lük ek gaz talebinin yakın dönemde oluşacağını 
hesaplamıştır (GAZPROM, 2009: 6).

Balkanların hem gaz talebi hem de bölgede mevcut uluslararası doğal gaz hatları bakımından gelişime açık olması, konunun ilgili aktörlerinin boru hattı siyasetlerindeki algılamalarını da belirlemektedir. Son zamanlarda 'Geniş Karadeniz Bölgesi' kavramının ön plana çıkması Hazar'dan Adriyatik denizine kadar olan coğrafyada enerji kaynaklarının arama-üretim-iletim aşamalarında Balkan coğrafyasının bu algıların belirlenmesindeki rolünü ortaya koymaktadır. Zira Geniş Karadeniz Bölgesi'nin doğusundaki ülkeler üretici, batısındakiler ise tüketici konumdadır ve her iki kesimin ortak paydası ise Avrupa üzerinden Batı sistemine eklemlenmede geçiş coğrafyalarında yer almalarıdır. Bu nedenle, artan gaz talebini firsat olarak görüp bölgeye ulaşmak isteyen şirketler ve Balkan coğrafyasında boru hatları jeopolitiği üzerinden nüfuzunu arttırmak isteyen çeşitli aktörler enerji kaynaklarının taşınması üzerindeki projelere yönelik olarak kendi güç algılamaları çerçevesinde farklı yaklaşımlar sunmaktadırlar. Bu aktörler arasında yer alan Türkiye, Avrupa'nın Rusya'ya olan ağır gaz bağımlılığını azaltma politikası ekseninde kendisini Rusya dışında geliştirilen Avrupa merkezli projelerde alternatif bir güzergâh olarak konumlandırmaktadır. Rusya ise Avrupa piyasalarındaki hâlihazırdaki hâkim durumunu, alternatif olarak geliştirdiği kendi boru hattı projeleriyle sağlamlaştırma ve mevcut transit risklerden kaçınma politikasını izlemektedir. Bu bağlamda, Rus stratejisinde gaz boru hattı projeleri özelindeki ana hedef güzergâh çeşitliliği iken, Türkiye için bu amacin AB örneğinde olduğu gibi kaynak çeşitliliği olarak belirlendiğini tespit etmek mümkündür. Bu yaklaşımın temel nedeni ise Rusya gibi üretici ülkeler için enerji güvenliği denilince gaz 'talep güvenliği'; Türkiye ve AB gibi ithalatçı ülkeler için ise gaz 'arz güvenliği' kavramlarının algıda öncelik taşımasıdır. Bütün bunların yanında, enerji güvenliği kavramının son zamanlarda giderek daha fazla önem kazanan 'transit güvenliği' boyutuyla üçayaklı bir yapıya büründüğü dikkate alındığında ise bu son boyutun AB'den ziyade Rusya ve bilhassa Türkiye ve Balkan ülkeleri açısından daha ön planda olduğu değerlendirilmektedir.

AB-Rusya-Türkiye arasındaki bu üç köşeli oyunda tarafların kendi çıkarları ve aralarındaki ikili ilişkiler yakından incelenmek suretiyle özellikle Hazar kaynaklarının başta Balkanlar olmak üzere Avrupa'ya aktarımını öngören doğal gaz boru hattı jeopolitiğinin seyri hakkında fikir edinmek mümkün olabilecektir.

\section{Balkanlar Enerji Güvenliği İçin Geliştirilen Doğal Gaz Boru Hattı Projeleri ve AB-Rusya Rekabetinin Nedenleri}

Enerji kaynaklarının kontrolünün bu denli önem kazandığı günümüzde Rusya'nın doğal gaz iletim ve dağıtım hatlarını kullanarak hem kendi hem de komşu coğrafyasında edinmiş olduğu etkin konumdan bilhassa rahatsızlık duyan $\mathrm{AB}$, farklı gaz kaynaklarına ulaşma çabasını hareketlendirmek durumunda kalmıştır. Bu doğrultuda, son yıllarda gaz piyasalarında yaşanan kaya gazı ve sıvılaştırılmış doğal gaz (LNG) projelerinin yanında özellikle Hazar, Akdeniz ve Orta Doğu doğal gazı AB için Rusya'ya alternatif kaynak oluşturması nedeniyle giderek önem kazanmaktadır. Avrupa Komisyonu'nun stratejik inisiyatifiyle, 2008 yılında ilgili kaynakları emmek ve kendi 
komşu coğrafyasındaki dış etkileri dengelemek amacıyla 'Güney Gaz Koridoru' kavramını geliştirdiği bilinmektedir (Commission of the EC, 2008: 4). Bu projelere örnek olarak birbirini tamamlayan ve ayn zamanda birbirine rakip olan NABUCCO West, TransAnatolian Pipeline (TANAP), Transadriatic Pipeline (TAP) boru hatt1 projeleri gösterilebilir (Mamedov, 2013). Bu projeler kaynak olarak başlıca Şah Deniz 2, Kuzey Irak ve Doğu Akdeniz gaz yataklarını hedeflemektedir.

Aslında bütünleşik bir Avrupa enerji piyasasından bahsetmek henüz tam olarak mümkün değilse de $\mathrm{AB}$ ülkelerinin birçoğunda doğal gaz piyasası için benzeri bir hukuki düzenleme ve fiyatlandırma sisteminin varlığını belirtmek gerekmektedir. Avrupa Komisyonu, 2009 yılında çıkarttığı 3. Enerji Paketi çerçevesindeki hukuki düzenlemeleri üye ülkelerin mevzuatına uygulamak suretiyle Avrupa entegrasyonunun bir parçası olarak AB ortak gaz piyasasını oluşturmak adına önemli mesafe kat etmektedir (Jukov et.al. 2010: 68). Aynı zamanda, $\mathrm{AB}$, kendi iç pazarının doğal bir uzantısı olarak algıladığı Balkan ülkeleriyle 2005 yılında Atina'da imzaladığı anlaşmayla Avrupa Enerji Topluluğu'nun temelini atarak Balkan ülkelerinin iç enerji mevzuatlarını da 2015 yılına kadar AB'ye uyum gösterir hale getirmesini amaçlamaktadır (Kaveşnikov, 2009). AB ile dokuz Balkan ülkesi arasında imzalanan anlaşmanın temel hedefleri şunlardır: Bölgesel bazda bütünleşik bir elektrik ve gaz piyasası oluşturularak bu daha geniş ölçekteki $A B$ ortak enerji pazarına entegre etmek. Gaz iletim, dağıtım ve depolamada ortak kurallar benimsemek. Ulusal ölçekte enerji piyasalarını denetleyecek/düzenleyecek kurumlar inşa etmek ve bağımsız iletim sistem operatörleri oluşturmak. Üçüncü taraf erişimini sağlamak ve enerji ticaret serbestliğinin önündeki rekabeti engelleyici koşulları ortadan kaldırmak (Rachev, 2012). $\mathrm{Bu}$ amaçlara ulaşılmada $\mathrm{AB}$ 'nin yavaş davrandığı çünkü üye ülkeler arasında dahi bazı sorunların bulunduğunu, ayrıca Rusya’nın etkisini kırmanın bölge ülkeleriyle yaptığı ikili anlaşmalar nedeniyle kolay olmadığı zamanla anlaşılmıştır. Balkan enerji piyasasının uzun yıllar süren savaştan olumsuz etkilenen altyapısının modernleştirilmesindeki güçlük ve yetersiz yatırım miktarı da düşünüldüğünde $\mathrm{AB}$ 'nin Balkanlar için geliştirdiği Enerji Topluluğu konsepti umulan etkiyi gösterememiş ve entegrasyon yeterince başarılı olamamıştır.

Kaynak çeşitliliğine katkı olarak piyasalara ulaştırılması düşünülen Hazar ve Orta Doğu doğal gazının ana hedef pazarı olan $\mathrm{AB}$ ülkelerinde 2008 dünya iktisadifinansal krizinin ardından toplam gaz talebinde yaşanan düşüş bu projeksiyonların gerçekleşmesini de zorlaştırmıştır. Gerek yerli üretim miktarlarının azalması, gerekse konvansiyonel olmayan gaz kaynaklarının $\mathrm{AB}$ içindeki üretim potansiyelinin yakın gelecekte somut bir alternatif sunmaması nedeniyle, ithalata duyulan ihtiyacın artması mutlak gözükmekte ve bu da boru hatları rekabetinin kızışmasında önemli bir rol oynamaktadır. $\mathrm{AB}$ açısından kendi gaz piyasasındaki kaynak çeşitliliğinin yanında Rusya'yı devre dışı bırakacak boru hattı projeleri sayesinde AB'ye komşu olan Balkan coğrafyasının temel yönelimini Brüksel'e çevirmek esas teşkil etmektedir. Bu bakımdan $\mathrm{AB}$, mesele enerji nakil hatları olduğunda Balkan coğrafyası üzerindeki kendi etkinliği için küresel bir enerji devi olan Rusya'yla ilişkilerinde dikkatli davranmaktadır. Rusya'nın ihraç ettiği enerji ürünlerinin halen büyük çoğunlukla Avrupa pazarına yöneldiği gerçeği de mevcut duruma eklendiğinde bu alanda AB-Rusya arasındaki enerji diplomasisinin 
Balkan Piyasalarını Hedef Alan Doğal Gaz Boru Hattı Projeleri Arasında Rekabet:

NABUCCO-Güney Akım ve Trans-Adriyatik Boru Hattı (TAP) Projeleri Örneği

önemi açıktır.

Yukarıda belirtildiği üzere, enerji nakil hatları denilince $\mathrm{AB}$ açısından temel endişe kaynak çeşitliliği iken, Rusya açısından boru hattı politikalarının temel dinamiği farklı işlemektedir. Rusya'nın, Sovyetler Birliği zamanında inşa edilen ve kendi 'yakın çevre' coğrafyası olarak kabul ettiği Belarus, Ukrayna gibi ülkelerden geçerek Avrupa pazarlarına ulaşan boru hatlarına ilaveten güzergâh çeşitliliği stratejisi çerçevesinde ilk gerçekleştirdiği büyük doğal gaz boru hattı projesi $16 \mathrm{mmk}$. kapasiteli ve 2003 yılında işletmeye alınan Mavi Akım boru hattıdır. Karadeniz'in altından geçerek Türkiye'ye ulaşan bu hattın yanı sıra, Baltık Denizi altından geçerek doğrudan Almanya'ya uzanan 55 mmk. kapasiteli Kuzey Akım doğalgaz boru hattı da 2011 yılı sonunda faaliyete geçmiş ve nihai yatırım kararı alınan Güney Akım doğalgaz projesinin temeli de 7 Aralık 2012 tarihinde Rusya'nın Anapa kentinde yapılan törenle atılmıştır. Bu itibarla, AB'nin Güney Gaz Koridoru transit projelerine cevaben Rusya da kendi tasarladığı 'Güney Gaz Linki' kavramını uygulama aşamasına geçirmiştir (RF 2030 Enerji Stratejisi, 2009). Güney Akım'ın en önemli bileşenini oluşturduğu kabul edilen Güney Gaz Linki kaynak bazı olarak Sibirya bölgesi ve 20 mmk. kapasitelik Hazar yanı boru hattı vasitasıyla Orta Asya kaynaklarını hedeflemektedir. Rusya kontrolü altında kalacak olan bu kaynakların Karadeniz üzerinden Balkan coğrafyasına iletimi 'Güney Gaz Linki'nin özünü teşkil etmektedir. Güney Gaz Linki’nin mihenk taşı olan ve yine Karadeniz’in altından geçip Bulgaristan'a ulaşarak Güney Avrupa ve Balkan ülkelerinin gaz arz ihtiyacını karşılayacak olan Güney Akım doğalgaz boru hattı, aynı zamanda Rusya için çok önemli bir itibar projesi niteliği de taşımaktadır. Hattın kara kısmının inşaatı için ilgili ülkelerle transit rejimini düzenleyen Hükümetler arası anlaşmalar imzalanmıştır. Hattın Bulgaristan'dan sonra Yunanistan ve İtalya'ya, Sırbistan üzerinden de Bosna Sırp Cumhuriyeti dahil diğer Balkan ülkelerine toplam kapasite olarak yılda $63 \mathrm{mmk}$. doğal gazı ulaştırması öngörülmektedir. Güney Akım doğal gaz boru hattı Karadeniz'de Rus GAZPROM (\%50), İtalyan Eni (\%20), Fransız Edf (\%15) ve Alman Wintershall (\%15) şirketlerinin ortaklığında yürütülen uluslararası bir projedir (GAZPROM web sayfası, 2013).

Güney Akım’ın siyasi sahibi olan Rusya, yine bu boru hattı sayesinde özellikle Güneydoğu Avrupa ülkelerinin gaz altyapılarında muazzam bir etkiye sahip olmayı amaçlamaktadır. Böylece Yugoslavya'nın dağılmasından sonra Güney Akım ile Rusya, tüm Balkanlara aktif bir oyuncu olarak geri dönme olanağına kavuşacaktır. Hattın geçeceği ülkelerde hâlihazırda ana gaz tedarikçisi konumunda bulunan Rusya, bu pazarlara olan mevcut ihracat miktarlarını yukarıya çekmek ve kendi gazına rekabet yaratacak alternatifleri engellemek istemektedir. Surbistan'ın bu bağlamda Rusya için önemi büyüktür. Sırbistan enerji altyapısına sahip devlet petrol ve gaz şirketi N.I.S'in kontrolünün \%51'i GAZPROM'un eline geçmiştir (Pavlovska, 2010) Ayrıca GAZPROM ve Srbijagas şirketleri 2011'de Banatski Dvor'da senelik 450 milyon metre küp kapasiteli yeraltı gaz depolama tesisi kurulması üzerine anlaşmaya varmışlardır. Bu bölgedeki en büyük doğal gaz depolama yatırımı olarak dikkat çekmektedir (Oilprice, 2012).

Rusya'nın bu projeyle birlikte jeopolitik olarak önem arz eden Balkanlar ve daha geniş olarak tüm Avrupa'daki varlığını kuvvetlendirmek istemesinin bir başka nedeni 
de en son 2009 yllında meydana gelen Rusya-Ukrayna gaz ihtilafindan yirmiden fazla Avrupa ülkesinin etkilenerek kayda değer miktarda Rus gaz ihracatının sekteye uğramasıdır. Örneğin, bir Balkan ülkesi olan Bulgaristan tükettiği gazın tamamını Rusya'dan satın alırken bu oran Batı Avrupa ülkesi olan İtalya'da ancak toplam tüketimin dörtte birine kadar gerilemektedir (Andres-Kofman, 2011: 1-3). Rusya Federasyonu açısından bu proje, çeşitli Avrupa ülkelerine yeni bir altyapı yatırımı olarak geri dönmesi ve geniş anlamda güzergâh çeşitliliğine katkı sunması nedeniyle Avrupa arz güvenliğini de sağlamlaştıracaktır. Güney Akım'dan önce planlanan Kuzey Akım projesi hayata geçmeden önce Avrupa pazarlarına ulaşan Rus gazının \%80 oranında Ukrayna'dan geçtiği düşünüldüğünde Kuzey ve Güney Akım doğal gaz boru hatlarının bitimiyle birlikte manzara tamamen tersine dönecek ve Rusya Federasyonu son y1llarda düzenli olarak karşılaştı̆̆ 1 transit risklerden kaçınmış olacaktır. GAZPROM, 2009'daki son krizin ardından yaşanacak maddi külfeti ve itibar kaybını artık fazlasıyla önemsemek durumunda kalmaktadır (Rettman, 2013). Proje tamamlandığında Rusya tarafindan Avrupa enerji güvenliği için güvenilmez olarak addedilen Ukrayna, Moldova ve Romanya gibi ülkeler etkisiz hale gelecektir.

Rusya'nın aslında Güney Akım boru hattını yüksek maliyeti nedeniyle gerçekleştirmekte 1srarcı olmayacağı ve bu projeyi sadece Ukrayna üzerinde baskı olarak kullandığı bazı çevrelerce iddia edilmektedir. Aslında Ukrayna milli petrol şirketi 'NAFTOGAZ'ın tasarrufunda bulunan Ukrayna gaz transit sisteminin GAZPROM tarafından Belarus örneğinde olduğu gibi satın alınması gündeme gelmiş, fakat bu Ukrayna'nın sert direnişi nedeniyle gerçekleşememiştir. Bunun üzerine söz konusu sistemin AB-Ukrayna-Rusya üçlüsünün ortak olacağı bir yapı tarafından satın alınması ve gerekli modernizasyonun yapılması fikri ortaya atılmış, fakat bu öneri de Ukrayna'nın kendi egemenliği ve ülkenin ekonomik güvenliğine tehdit teşkil edeceği gerekçesiyle hayat bulamamıştır (Geropulos, 2013: 1). Bununla birlikte Avrupa Komisyonu başkanı Ötinger, Güney Akım projesine üçüncü taraf erişimine yönelik bağımsız üreticilerin de hak edinmesi gerektiğini savunmuş ve Rusya'ya bu konuda $A B$ kanunlarınca istisnai bir durumun tanınmasının gündemlerinde olmadığını belirtmiştir (Pop, 2011). AB'nin kaynak çeşitliliği stratejisiyle bağdaşmayan bu proje Rusya Federasyonu'nun, Kuzey Akım örneğinde olduğu gibi Güney Akım için de $\mathrm{AB}$ 'den özel statü istemesine rağmen $\mathrm{AB}$ için bir öncelik teşkil etmemektedir. Bunun gerçekleşmemesi halinde Güney Akım, AB 3. Enerji Paketi bünyesinde değerlendirilecek ve hat $\mathrm{AB}$ karasal topraklarından geçtiği anda boru hattı kapasitesinin \%50'si oranında üçüncü tarafların hatta erişimi mümkün olacaktır. $\mathrm{Bu}$ da GAZPROM açısından istenmeyen ve projenin mali karlılığını düşüren bir durumdur. AB ile Rusya arasındaki 2009 yılında kabul edilen 3. Enerji Paketi kaynaklı bu ve benzeri gerilimler yine AB komisyonu tarafından 2012 yılında GAZPROM aleyhine açılan rekabet soruşturmalarıyla daha da çetrefil bir hal almıştır. Güney Akım boru hattının da bu kapsamda ikili AB-Rusya Enerji Diyaloğu çerçevesinde değerlendirilerek taraflar arasındaki pazarlıkların bir unsurunu oluşturması muhtemel gözükmektedir. 


\section{AB-Rusya Arasında Üçüncü Bir Aktör Olarak Türkiye ve Türk Enerji Diplomasisi'nin Öncelikleri}

Gerek Güney Gaz Linki gerekse Güney Gaz Koridoru'nun gerçekleştirilmesi konusunda kilit ülke ise hiç kuşkusuz transit konumu nedeniyle Türkiye'dir. Bilindiği üzere Türkiye'nin doğusunda dünya petrol ve gaz yataklarının yaklaşık \%70'i bulunmakta, batısında ise dünyanın yine en büyük enerji tüketim bölgelerinden biri olan büyük Avrupa pazarı yer almaktadır. Üstelik hızla artan enerji talebiyle ülkenin kendisi de önemli bir pazar olmaya başlamıştır. 2012 senesinde yaklaşık 120 milyon ton petrol eşdeğeri olan birincil enerji kaynaklarının tüketiminin biraz abartılı olsa da 2020'de 222 milyon tona ulaşması beklenmekte, ancak buna rağmen ülke, enerji ihtiyacının 4'te 3'ünü de ağırlıkla gaz ve petrol ithalatıyla karşılamaktadır (Yazar, 2010: 5). Net enerji ithalatçısı ülkeler arasındaki bu kayda değer durumu, Türkiye'nin doğal olarak başta doğu-batı enerji koridoru olmak üzere bir takım uluslararası enerji projelerine katılımını da gündeme getirmektedir. Bunların yanında Türkiye, daha az vurgulansa da Mavi Akım, Samsun Ceyhan gibi kuzey-güney enerji geliştirme projelerine de önemli bir katkı sağlamaktadır. Zaten bir tarafta devlet ağırlıklı bir tarafta liberal piyasalar, bir tarafta enerji üreticisi öbür tarafta tüketicisi ülkeler ve bir tarafta otoriter diğer tarafta demokratik rejimlerle çevrilen Türkiye, kendi bünyesinde barındırdığı özellikler bakımından iki dünyaya da ait bir görünüm arz etmektedir. Bakü-Tiflis-Ceyhan ham petrol, Bakü-Erzurum, Mavi Akım, Türkiye-Yunanistan, İran-Türkiye doğal gaz boru hatlarının gerçekleşmesi Türkiye'nin bu konumuna büyük katkıda bulunmuşken, sıradaki projelerle birlikte Türkiye'nin enerji sahasında çok daha etkin bir oyuncu olma konumuna yükselmesi beklenmektedir. $\mathrm{Bu}$ bakımdan Türkiye'nin Avrupa'nın dördüncü gaz arteri olması, AB'nin Güney Gaz Koridoru bünyesinde değerlendirilen bir takım projelerin hayat bulması ile doğru orantilidir.

Son on yıllık süre zarfında NABUCCO Güney Gaz Koridoru projeleri arasında en çok ilgi çekeni olagelmiştir. 2009 Temmuz ayında Ankara'da Türkiye'nin doğu sınırlarından Avusturya'ya kadar boru hattının yapımı için hattın üzerinden geçeceği ülkeler arasında Hükümetler arası anlaşma imzalanmıştır. İmza töreninde hazır bulunan Avrupa Komisyonu Başkanı Barroso, bu anlaşmayla AB'nin Türkiye ile enerji ilişkilerinde yeni bir döneme girdiğini belirtmiş ve $\mathrm{AB}$, Türkiye ve Hazar ülkeleri arasında yeni bir yapısal dönüşümün gerçekleşeceğinden bahsetmiş̧tir (Barroso, 2009). Bu doğrultuda 6 Temmuz 2011'de yine hattın transit geçeceği ülkeler arasında (Türkiye, Bulgaristan, Romanya, Macaristan, Avrupa) proje destek anlaşması imzalanmıştır. Bu anlaşmayla NABUCCO projesi $\mathrm{AB}$ enerji mevzuatı içerisinde muafiyet kazanmış ve projenin teknik gelişimi önündeki engeller verilen teşviklerle bertaraf edilmiştir (Haberturk, 2011).

Bütün bu gelişmelerin yanı sıra AB-Türkiye arasında gaz transit projeleri konusunda net bir uyumun olduğunu iddia etmek güçtür. Konu biraz daha yakından incelendiğinde, Türkiye'nin Rusya, Norveç ve Cezayir'den sonra Avrupa'nın dördüncü gaz arteri olma stratejisinin AB'nin Güney Koridoru projesiyle çakışmasının Türkiye'ye $\mathrm{AB}$ enerji güvenliğinin sağlanmasında salt bir transit rol değil, bunun daha ötesinde 'HUB' 
olma firsatı da sunma potansiyeli olduğu görülecektir. Türkiye, kendi enerji ithal kaynaklarını çeşitlendirmenin yanı sıra üstleneceği daha büyük rolle enerjide sözü dinlenen bir aktör olmayı hedeflemektedir. $\mathrm{AB}$ tarafından bakıldığında ise Türkiye'nin $\mathrm{AB}$ enerji güvenliği içindeki rolünün transitten 'HUB' a doğru kayması da birliğin menfaatleriyle uyuşur görünmemektedir. İki taraf arasındaki bu yaklaşım farklılığı ortak çıkarların oluşumu ve uygulanmasına da engel oluşturmaktadır. Ayrıca AB tarafından Türkiye'nin NABUCCO'yu AB'ye tam üyelik için bir koz olarak kullandığı yorumları da yapılmaya başlanmıştır (Euuropean Policy Center, 2009). Kısacası Türkiye, AB için salt transit bir ülke olarak ikinci bir Ukrayna olmak istememekte, GAZPROM'dan kurtulmayı düşleyen $\mathrm{AB}$ ise kapısında ikinci bir GAZPROM'la muhatap olmayı arzu etmemektedir.

Türkiye'nin bazı gaz tedarikçileriyle imzaladığı anlaşmalardan edindiği 'reeksport' hakkı ülkenin sadece gaz transiti değil, aynı zamanda gaz fiyatının belirlenip gazın Avrupa'ya satılacağı bir 'HUB' olmasına hizmet edecek bir koz iken, AB için Türkiye transiti üzerinden doğrudan kaynak sahibi ülkelerle pazarlığa oturmak esastır. 2007 yılında açılan Türkiye-Yunanistan doğalgaz boru hattı Türkiye'nin yukarıda belirtilen amacına hizmet etme açısından başarıya ulaşan ilk projedir. 2001 yılında Türkiye ve Azerbaycan arasında imzalanan ilgili sözleşme uyarınca Türkiye Azerbaycan Şah Deniz 1 yataklarından satın aldığı 750 milyon metre küplük gazı belirli bir kar üzerinden Yunanistan'a ihraç etme hakkına sahip olmayı başarmıştır. Bu sayede ilk defa bir AB ülkesi Hazar gazına Rusya dışı bir alternatiften ulaşmıştır. Türkiye, Rusya ve İran gazı için de gazı tedarik ettiği GAZPROM ve NIGC şirketlerinden de benzeri talepte bulunmuş, ancak üretici ülkelerin muhalefeti ve daha sonraki gelişmeler neticesinde bu isteğinden vazgeçmeyi tercih etmiştir. Dahası Türkiye, 2001 yılında imzalanan sözleşmeyle Şah Deniz 1 için edinmiş olduğu re-eksport hakkından yine Azerbaycan'la imzaladığ Deniz 2 kaynağı odaklı TANAP anlaşması sırasında feragat etmiş, bu da TANAP'ın Türkiye için NABUCCO'ya göre daha avantajlı görünmesine karşın ülkenin 'HUB' olma stratejisinden vazgeçebileceği yorumlarına neden olmuştur (Hava, 2012).

Türkiye'nin Avrupa enerji güvenliğine katkıda bulunmaktan daha önce temel endişesinin kendi enerji güvenliğini sağlamaya yönelik Rusya dışı üçüncü ülkelerden gaz ve petrol ithalatını arttırmak olduğu gerçeği de Türkiye'nin bu alandaki konumunu özgünleş̧irmektedir. Bunun yanında, Rusya'yla enerji işbirliğini derinleştirmesinin Türkiye'ye Moskova'yla ve Rusya'nın da Ankara'yla daha kapsamlı ticari ilişkilerin geliştirilmesinde önemli firsatlar sunuyor olması da meseleyi daha karmaşı hale getirmektedir. $\mathrm{Bu}$ nedenle, enerji kaynaklarının aktarımı konusundaki mevcut bulunan politika farklılıklarına rağmen son yıllarda iki ülke arasında ekonomik işbirliğine yönelik olarak olumlu gelişmeler gözlemlenmeye başlanmıştır. İkili ticaret hacmi aşırı dengesiz biçimde Türkiye aleyhine olsa da 2012 senesinde 33 milyar doları bulmuş ve yakın gelecek için 100 milyar dolarlık bir rakam hedeflenmiştir (Milliyet, 2013). Türkiye'nin on yıllardır sürekli artan enerji talebinin karşılanmasında dünyanın en büyük enerji ihracatçısı olan Rusya Federasyonu'yla yakın coğrafyada bulunması, kuşkusuz iki ülke arasında gelişen çok boyutlu enerji işbirliğinin temel sebebini oluşturmaktadır. İkili enerji işbirliğinin çekirdeğinde ise doğal gaz yer almakta ve diğer alanlarda gelişen ilişkilere de önayak olmaktadır. Bununla birlikte, yıllardır büyük sorunlar olmaksızın süregelen iki ülke 
enerji işbirliğinde tarafların çıkarlarının potansiyel olarak çatıştığı alan ise açıkça söz konusu kaynakların üçüncü ülkelere iletilmesi üzerine geliştirilen uluslararası petrol/gaz transit projeleridir.

Türkiye ve Rusya'nın henüz 1997 yılında Mavi Akım anlaşmasını imzalayarak aracısız gaz ticaretine başladıkları düşünüldüğünde bu hat sayesinde Rusya'nın Türkiye üzerindeki iktisadi ve siyasi ağırlığını giderek arttırdığına tanıklık edilmiştir. Ayrıca Türkiye, Almanya'dan sonra GAZPROM'un en büyük ikinci müşterisi olmuş ve süreç içerisinde Rus gazına orantısız olarak gitgide bağımlı bir hale gelmiştir. Bu da ülkenin Rusya karşıtı dış politika tercihlerini yeniden gözden geçirmek durumunda kalmasına sebebiyet vermiştir (Özdemir, 2007). Bu boru hattının devamı olarak Putin, 2006 yılında Mavi Akım 2'nin yapımını önermiş ve hedef pazarlar olarak da ilkin Orta Doğu sonrasında ise Avrupa ülkelerini göstermiştir (Milov, 2007). Fakat bu konuda ilerleme sağlanamayınca Güney Akım doğalgaz boru hattı projesi yine Rusya tarafindan NABUCCO'ya rakip olarak ortaya çıkarılmıştır.

Aslında Mavi Akım 2, daha önceden aynı yerden geçen bir boru hattı olması hasebiyle maliyet ve fizibilite açısından tarafları tatmin edecek bir proje niteliğindedir. NABUCCO ve bilhassa Güney Akım gibi maliyeti yüksek ve inşası uzun projelerden ziyade Mavi Akım 2 teknik olarak yapımı son derece makul bir proje olarak gözükmektedir. Ancak asıl önemlisi bu proje sayesinde Rusya'nın Avrupa'daki ana gaz tedarikçisi konumunu güzergâh çeşitliliği hedefine uyumlu bir şekilde daha az maliyetle (Güney Akım'ın bedelinin 30-35 milyar dolar olduğu düşünüldüğünde) pekiștirme imkanı ve Türkiye'nin de yine Avrupa'nın enerji güvenliğinde önemli bir merkez olma hedefine bir adım daha yaklaşma olanağı bulmalarıdır. Bu nedenle söz konusu proje iki tarafın da çıkarlarına hizmet edebilme potansiyeline sahiptir. Ayrıca Türkiye, Mavi Akım'dan kaynaklanan Rusya'ya orantısız bağımlılığını Mavi Akım 2'yi gerçekleştirip Rus gazı için transit bir geçiş olma suretiyle dengeleme imkânına kavuşabilecekken proje eyleme dökülememiştir. Rusya Devlet Başkanı Vlademir Putin, 3 Aralık 2012 tarihinde Dolmabahçe'de düzenlenen Rusya-Türkiye ikili zirvesinden sonra basın mensuplarına Rusya'nın Mavi Akım'ın genişletilip Rus gazının Türkiye üzerinden üçüncü ülkelere açılması fikrine açık olduğunu vurgulamıştır (Kolesnikov, 2012). Buna rağmen Rusya, Güney Akım iznini aldıktan sonra Türkiye'yi Doğu-Batı ve Kuzey-Güney doğal gaz hatlarının kesiştiği bir merkeze dönüştürecek böylesine büyük bir kozu hele ki Suriye nedeniyle ikili ilişkilerin gerginleştiği bir ortamda Türkiye'ye vermek istememektedir.

Daha genel resimde ise Rusya'nın Avrupa'nın güney pazarlarına ulaşacak her türlü proje için Türkiye'nin desteğine ihtiyaç duyduğu görülmektedir. Bir yandan Ukrayna'nın meydana getirdiği transit risklerinden kurtulmak isteyen Rusya, Türkiye'yi de yeni bir Ukrayna yapmak istememekte ancak öbür yandan Türkiye'nin desteği olmadan da ana hedefine ulaşmakta güçlük çekmektedir. Boru hatları jeopolitiğindeki bu güç mücadelesi yukarıda belirtildiği gibi 28 Aralık 2011 tarihinde Ankara'nın Rusya'ya Güney Akım'ın Karadeniz altındaki Türkiye'nin kendi münhasır ekonomik alanından geçişine inşaat izni vermesiyle yeni bir boyut kazanmıştır. Bu doğrultuda, Rus tarafı şimdilik makro planlarını devreye sokabilme başarısını göstermiştir. Üstelik Türkiye ile Rusya arasındaki 
müzakerelerde bir başka konu alanı olan günlük 1.5 milyon varil kapasiteli ve Rus devlet şirketleri ROSNEFT, TRANSNEFT, İtalyan ENI ve Türkiye'den Çalık şirketlerinin iştirak ettikleri Samsun-Ceyhan ham petrol boru hattı projesinde bir ilerleme sağlanamamış ve Türkiye'nin Ceyhan'ı uluslararası bir petrol terminaline dönüştürme hedefi akamete uğramıştır (Hürriyet Daily News, 2011). Rusya açısından Güney Akım doğal gaz, Türkiye için ise Samsun-Ceyhan ham petrol boru hattı projeleri stratejik önem arz ederken, Türk tarafının Rusya Federasyonu'na göre enerji diplomasisinde bir adım geride kaldığ değerlendirilmektedir. Türkiye'nin geçmiş dönemden kalan kısa vadeli 'al ya da öde' hükümlü borçlarını ileriki döneme devretmek dışında Rusya ile yaptığı pazarlıktan dengeli bir kazanım elde edemeden Güney Akım'a inşaat izni vermesi sorgulanmaya açıktır. Öyle ki, böylesine önemli bir avantajı ummadık bir zamanda elde eden Rusya'da, dönemin Başbakanı ve şimdiki Devlet Başkanı Vlademir Putin, söz konusu izin için Türkiye'nin kendilerine yeni yıl hediyesi verdiğini hatırlatmış ve Moskova'nın bu konudaki büyük sevincini yansıtmaktan çekinmemiştir (Hürriyet, 2011).

Üç aktörün kendi çıkarları ve birbirleri arasındaki ikili ilişkilerin gidişatı yanında Hazar'a komşu ülkeler de Avrupa pazarlarına ulaşmak için farklı projelerle ilgilenmeye başlamıştır. Sovyet dönemi sonrası inşa edilecek yeni boru hatları sayesinde Hazar ülkeleri yalnızca gelirlerini artırmayı değil, aynı zamanda üzerlerindeki GAZPROM tekelini de kırmayı amaçlamaktadırlar. Bu bağlamda, Sovyetlerin yıkılmasından sonra Hazar'ın doğusundaki kaynaklar söz konusu olduğunda kaynakların Batı'ya yönelimi gerçekleşmemiş, Rusya'ya ek olarak Kazak petrolü ve Türkmen gazı Doğu’ya yani Çin pazarına akmaya başlamıştır. Bu sayede Rusya'nın yanında ilgili ülkelerde Çin'in etkinliği artmaya başlamıştır. Azerbaycan için ise durum tam tersi bir görünüm arz etmektedir. Bakü-Tiflis-Ceyhan ve Güney Kafkasya boru hatlarıyla Azeri petrol ve gazı Türkiye üzerinden Batı'ya yönelmiş, Azerbaycan'da Rusya dışında 'Batı' kurumları ve Türkiye'nin etkinliği hissedilir ölçüde yükselmiştir. Üretime 2018 yılında geçmesi planlanan Şah Deniz 2 yatakları mevzubahis olduğunda güzergâh seçimi olarak yine Türkiye üzerinden geçmesi planlanan boru hattı için Azerbaycan'la Türkiye arasında 2011'deki İzmir anlaşması uyarınca TANAP seçeneği belirlenmiş ve bu suretle NABUCCO projesi de ilk büyük darbesini almıştır (Reuters, 2012). TANAP sayesinde Azerbaycan çok önemli bir kazanım elde etmiştir. TANAP'ın gerçekleşmesi NABUCCO'ya nazaran Rusya açısından da aslında daha makul bir durum oluşturmuştur. Rusya için Azerbaycan'dan yüksek fiyatla gaz alıp Avrupa'ya yeniden ihraç etmenin bedeli kendi gazını ya da ucuz Orta Asya gazını yeniden ihraç etmesine kıyasla oldukça yüksektir. Hattın başlangıç kapasitesi olan 16 mmk.lük bir miktar göz önüne alınarak yapılan tahminlere göre GAZPROM'un Azerbaycan gazını almaması, yaklaşık 3 milyar dolar tasarruf etmesi anlamını taşımaktadır (Komcherkin, 2011). Zaten GAZPROM, son yıllarda alımını 2 mmk.e kadar çıkardığ Azeri gazını kendi Kafkas bölgesi için kullanmakta, bu bölgenin talebi de yüksek seyretmemektedir.

Yeni inşa edilecek ve $6 \mathrm{mmk}$. gazın Türkiye'de tüketimini, $10 \mathrm{mmk}$. gazın da Avrupa'ya aktarımını öngören ve yaklaşık 10 milyar dolarlık bir yatırımla gerçekleştirilmesi öngörülen TANAP'ta Türkiye'nin toplam payı \%30, Azerbaycan devlet petrol şirketi SOCAR'ın payı \%58'dir. Ayrıca, Türkiye ile Azerbaycan arasında imzalanan 
Hükümetler arası anlaşmaya göre SOCAR'ın TANAP içindeki payı \%51'in altına düşemeyecektir. \%12'lik kısım BP'ye aitken başlangıçta STATOIL ve Total'in de projeye katılımı beklenmekteydi. (Natural gas Europe, 2012). Bu proje sonrasında NABUCCO yoluna Türkiye'nin Bulgaristan sınırından başlamak üzere NABUCCO West adı altında devam etmek durumunda kalmıştır. NABUCCO West ve TAP projeleri arasında TANAP anlaşmasından sonra yine TANAP'ın devamı olabilmek için büyük bir yarış başlamıştır. Şah Deniz 2 Konsorsiyumu 28 Haziran 2013'te, 2018'de Türkiye ve 2019'da Avrupa piyasalara ulaştırılması öngörülen Şah Deniz 2 gaz kaynağının Türkiye'nin batı sınırından başlayarak Avrupa'ya iletimi için NABUCCO West ve TAP projeleri arasındaki son tercihini açıklamış ve tercihini ikincisinden yana kullanmıştır. NABUCCO West projesinin bu süreçte neden batı Balkanlar üzerinden Güney Avrupa'ya ulaşacak olan TAP projesine kaybettiğini anlamak için $\mathrm{AB}$, Rusya ve Türkiye arasındaki üçlü enerji diplomasisindeki aktörlerin tutumlarının dikkatlice analiz edilmesi gerekmektedir.

\section{5. Şah Deniz Konsorsiyumu'nun TAP Projesini Tercih Etmesindeki Temel Etmenler}

Söz konusu doğal gaz boru hattı projelerinin nihai hedefinin yukarıda anlatılan ekonomi politik nedenlerle Balkan ülkeleri olduğu açıkken, bu projelerin ilgili aktörleri kendi çıkarlarını diğer iki aktöre rağmen gerçekleştirmenin zorluklarını görmüştür. Bunun yerine ikili uzlaşmalarla üçüncü tarafı yalnızlaştıracak politikaları benimsemek aşağıda açıklanan dinamikler nedeniyle daha rasyonel gözükmüş ve üç proje arasında yalnızlaşarak kaybeden günün sonunda NABUCCO olmuştur.

Aslında Balkan ülkeleri söz konusu olduğunda tarihi olarak Avusturya-RusyaOsmanlı İmparatorlukları arasındaki güç mücadelesinin 21. yüzyılda enerji hatları üzerinden yeniden ortaya çıktığını iddia etmek mümkündür. Bilindiği üzere Avusturya menşeli OMV şirketinin himayesinde gelişen ve önce NABUCCO daha sonra ise NABUCCO West şeklini alan doğal gaz boru hattı projesi Hazar gazının doğu Balkanlar üzerinden Orta Avrupa'ya ve oradan da Avusturya'da bulunana Merkezi Avrupa Gaz HUB'ına aktarımını öngörmektedir. Bu sayede merkezi Avrupa ülkelerini temsilen Avusturya menşeli OMV şirketi Baumagarten'ı önemli bir gaz dağıtım merkezi haline getirebilecek ve gaz ticaretinde ana oyuncu olarak daha sonra yine Avusturya üzerinden batı Balkan ülkelerine de bu gazın aktarımını sağlayacaktır. NABUCCO sayesinde başta Avusturya olmak üzere merkezi AB ülkeleri Balkan coğrafyasının gaz ihtiyacını kontrol ederek bölge üzerinde siyasi nüfuz da tesis edebilecektir. Güney Akım ise aynı pazarı hedefleyen Rusya projesidir ve aynı şekilde Güney Akım'ın gerçekleşmesiyle Rusya'nın siyasi nüfuzu Doğu Avrupa ve Balkanlar'da pekişecektir. TANAP sonrası seçilen TAP projesi ise her ne kadar nihai olarak İtalya pazarını hedef alsa da Balkan ülkelerini birleştiren İyonya-Adriyatik doğal gaz boru hattı vasıtasıyla Batı Balkan ülkelerini (Karadağ, Bosna-Hersek-Hırvatistan) Hazar gazıyla buluşturup, Türkiye’ye üçüncü bir yol üzerinden bu coğrafyada etkinlik sağlama olanağı tanıyacaktır. Zaten TAP ortakları da İyonya-Adriyatik doğal gaz boru hattı proje ortağı ülkelerle TAP'ın Şah Deniz Konsorsiyumu tarafından seçiminin öncesinde işbirliğine yönelik mutabakat zaptı 
imzalayarak bu konudaki kararlılıklarını göstermişlerdir (Reuters, 2013).

2000'lerin başındaki Bakü-Tiflis-Ceyhan ham petrol ve Bakü-Erzurum (Şah Deniz 1) doğal gaz boru hatları örneğinde olduğu gibi Azerbaycan kaynaklarının Batı'ya yönelimini engelleyemeyeceğini gören Rusya Federasyonu, kendisine rakip olan Azeri gazının batıya akışını en tehlikeliden daha az tehlikeliye yönelmesini yeğlemiştir. Rusya açısından en tehlikeli senaryo doğal gazda kendine \%100'e yakın oranda bağımlı olan Doğu Avrupa ülkelerinin bu bağımlılıktan kurtulmasına yol açacak olan NABUCCO projesinin gerçekleşmesi ihtimalidir. Bu proje yerine Batı'ya yönelimi kaçınılmaz görünen Azeri gazının Türkiye üzerinden Güney Avrupa-İtalya'ya ulaşması GAZPROM'un bu pazarlardaki konumunu çok değiştirmeyecek sadece sınırlı bir rekabet gerçekleşecektir. Bu açıdan bakıldığında Rusya açısından TAP ve NABUCCO arasında 'ehveni şer' olması bakımından Konsorsiyumca birincinin tercih edilmesi uygun gözükmektedir. NABUCCO'nun gerçekleşmesi ise Rusya açısından boru hatları jeopolitiğinde çok ciddi bir mağlubiyet olarak algılanmakta ve bu projenin engellenmesi için Rusya'nın Azerbaycan, Avrupa ve hatta Şah Deniz Konsorsiyumu şirketleri üzerindeki nüfuzunu kullanması zaruri addedilmektedir (Aleksiyev-Vasiliyev, 2013). Bu kapsamda, Konsorsiyumun kararından hemen önce Azerbaycan'ın devlet petrol şirketi SOCAR'ın Yunanistan'ın doğalgaz iletim şirketi olan DESFA'yı satın alması, GAZPROM ve diğer Rusya menşeli şirketlerin ise DESFA'nın ana şirketi olan Yunanistan doğal gaz şirketi DEPA'nın özelleştirmesinden çekilmesi manidardır. Konsorsiyum'un tercihini TAP'tan yana kullanmasında Azerbaycan-Rusya arasındaki bu zımni uzlaşmanın, daha önce TANAP'ta görülen NABUCCO'ya karşı Türkiye-Rusya işbirliğindeki gibi, önemli bir rolü olmuştur.

Birbirlerinden tamamen farklı güç odaklarına hizmet eden NABUCCO, Güney Akım ve TANAP-TAP projelerinde bölge dışı aktörlerin de sürece dâhil olması Konsorsiyumun kararını etkileyen başka bir faktördür. Bilindiği gibi Şah Deniz sahalarının geliştirilmesinde İngiliz BP en büyük hissedar olarak Norveç'li STATOIL şirketiyle birlikte belirleyici konumdadır. Yakın zamana kadar sıkıntılı olan İngiliz-Rus ilişkilerinde ise son zamanlarda yine BP'nin öncülük ettiği enerji anlaşmaları nedeniyle yumuşama görülmüştür. Rusya ve İngiltere arasında 2012 sonunda resmileşen Tnk-Bp/ROSNEFT anlaşmasını ROSNEFT-BP ve arasındaki Arktik offshore sahaları için işbirliği anlaşmaları izlemiştir (STATOIL, 2013). Söz konusu anlaşma uyarınca BP yarısına sahip olduğu TNK-BP şirketini ROSNEFT'e satmış, karşılığında ise Rus devlet petrol şirketi ROSNEFT'in ikinci en büyük hissedarı olmuştur. Bununla birlikte TAP projesinin sahiplerinden STATOIL ise aynı zamanda Şah Deniz Konsorsiyumunun diğer büyük ortağıdır ve bu şirketle yine ROSNEFT arasında benzeri bir Arktik anlaşması yakın tarihlerde gerçekleşmiş ayrıca GAZPROM'un birçok projede ortağı olan İtalyan ENI şirketi de ROSNEFT'le aynı alanda işbirliğine gitmiştir (RIA Novosti, 2013). TAP projesinin son ayağının İtalya olduğu düşünüldüğünde de Rusya'nın Şah Deniz Konsorsiyumu ortaklarıyla yaptığı anlaşmalar sonrası oluşan iklimde TANAP'ın devamı için NABUCCO West'e göre TAP projesinin bir adım daha öne çıkması şaşırtıcı olmamıştır.

Türkiye açısından ise resmi olarak devlet şirketi BOTAŞ vasıtasıyla ortak 
olunan NABUCCO projesi başından beri tartışmalı olmuştur. Türkiye'yi Avrupa enerji güvenliğinde salt bir transit haline dönüştürecek olan bu proje Ankara için büyük bir cazibe teşkil etmemiştir. NABUCCO projesinin 3'te 2'sinin Türkiye üzerinden geçmesine rağmen BOTAŞ'ın küçük ortak olarak kalması, projenin en büyük ortağı ve sahibinin ise Avusturya OMV şirketinin oluşu Ankara'nın NABUCCO'ya gönülsüz destek vermesine sebebiyet vermiştir. Nitekim Türkiye ilk firsatta bu konumdan kurtularak TANAP projesini desteklemiş ve NABUCCO'ya büyük bir darbe vurmuştur. Türkiye gerek kaynak gerekse imkân yetersizliği nedeniyle şimdilik 'HUB' olabilme yeteneğinden yoksun olduğu için bu hedefini göz ardı etmek durumunda kalmış, bunun yerine kendisini transit ülke ile HUB arasında konumlandıran TANAP projesine odaklanmıştır. TANAP'ta Türkiye'nin payı NABUCCO'ya nazaran yükselmiş ve daha da önemlisi bu hatta çoğunluk payı Azerbaycan'a (SOCAR) verilmiştir. SOCAR'ın Türkiye'deki yatırımları ve iki ülke arasındaki ilişkiler düşünüldüğünde TANAP'ın ortaya çıkışı Türkiye açısından son derece anlaşılır ve NABUCCO'ya göre avantajlı bir karar olarak değerlendirilmektedir. NABUCCO'nun NABUCCO West'e dönüşümünün ardından Türkiye'nin proje ortaklığı devam etmiş ancak bozulan Türkiye-AB ilişkileri sürecinde Türkiye bu projede yine gönülsüz davranmıştır. Fakat en önemlisi, Türkiye boru hattı savaşlarında AB çekirdek ülkelerinden ziyade BP ve STATOIL şirketlerinin konumunun belirleyici olacağını görmüş ve bu dönemde AB'den uzaklaşırken dış politikasındaki Anglo-Sakson yakınlaşmaya uygun biçimde İngiliz BP ve Amerikan ROSNEFT şirketlerinin Rusya ile anlaşmış olmalarına paralel olarak bu üçlünün yanına yaklaşmıştır.

Türkiye resmi olarak devlet şirketleri aracılığıyla TAP projesine iştirak etmek suretiyle Şah Deniz Konsorsiyumu'nun verdiği kararın ileriki yıllarda kazananları arasında yer alabilme esnekliğine sahiptir. TAP projesinin ilk aşamada Yunanistan'ın Türkiye sınırındaki Kipoi şehrini Arnavutluk üzerinden İtalya’nın Adriyatik kıyısındaki San Faco kentine bağlaması öngörülmektedir, proje kapsamında Arnavutluk'ta gaz depolama tesisi de inşa edilecektir. (TAP, 2014). Bu boru hattının Arnavutluk'tan sonra İtalya yerine Batı Balkan ülkelerine öncelik vermesini sağlayacak olan İyonya-Adriyatik Projesi'nin gerçekleşme ihtimali Türkiye'nin Balkan coğrafyasındaki etkinliğini arttırma emeliyle örtüşmektedir. Konsorsiyum kararından hemen sonra projenin gelişim aşamasında Türkiye'nin desteğini almak isteyen TAP ortaklarının kapılarının her zaman Türkiye'ye açık olduğunu belirtmesi de dikkat çekicidir (Taghieva, 2013). Türkiye açısından boru hattı diplomasisi henüz sonlanmamış, aksine TAP üzerinden Balkan ülkelerine açılma stratejisini gerçekleştirmek için yeni bir amaç ortaya çıkmıştır. Türkiye, TAP'ın yeni ortakları arasına girmede şimdilik edilgen durumdadır ama unutulmamalıdır ki TAP, gelecekte kaderi projeye katılacak ortakların birbirleri arasındaki tutumlarıyla şekillenecek bir projedir. Türkiye'nin SOCAR'la TANAP'ta kurduğu ortaklık Şah Deniz üretim sahasında TPAO’nun payını \%19'a çıkarmasıyla pekişmiştir. Ciddi mali yükün altına giren Türk şirketlerinin gelecekte Azeri ortaklarıyla beraber Batı Balkanlarda yeni projeleri kovalaması mümkündür ve bunu da ilk aşamada TAP'la gerçekleştirmek gerçekçi gözükmektedir (Özdemir, 2104) Zira Balkan coğrafyası için masada şu anda sadece TAP ve Güney Akım durmaktadır. Bahsedilen dinamikler nedeniyle TAP'ın kuzeye doğru genişleyerek Güney Akım'a rekabet yaratması kolay gözükmese de bu konu ileriki yıllarda 
da tartışılmaya devam edilecek ve Rusya'nın tekel konumu yine gündemden düşmeyecektir.

\section{Değerlendirme ve Sonuç}

Özet olarak, başlıca üç aktörlü Hazar kaynaklarının Avrupa’ya taşınması odaklı doğal gaz boru hatları projelerinden bahsedildiğinde Balkan coğrafyası için bu projeler arasındaki mücadelede sonuçta $\mathrm{AB}-$ Rusya-Türkiye arasındaki enerji diplomasisinin seyri önemli bir rol oynamıştır. NABUCCO başta Avusturya olmak üzere merkezi AB ülkelerin desteklediği bir projeyken Rus projesi Güney Akım ve Türkiye destekli TANAP-TAP projeleriyle rekabet etmek zorunda kalmıştır. Kabaca üç aktörü bu oyunda Rusya ve Azerbaycan-Türkiye arasındaki zımni uzlaşılar NABUCCO’nun üç proje arasında yalnız kalması sonucunu doğurmuştur. Bunun yanında, dünya enerji piyasaları ve uluslararası ilişkilerdeki gelişmeler de bu oyunun şekillenmesinde belirleyici bir etmen olarak ortaya çıkmıştır. Küresel enerji diplomasinin etkileri Hazar-Karadeniz-Adriyatik’teki boru hatları jeopolitiğine yansımış ve bu durum da zaten dev enerji şirketlerinin büyük hissedarı olduğu Şah Deniz Konsorsiyumu'nun NABUCCO West projesini elemesini kolaylaştırmıştır. Bu kapsamda, Rusya'nın kendi devlet petrol şirketi ROSNEFT üzerinden STATOIL, BP ve EXXONMOBILE şirketleriyle ortak projeler geliştirerek Norveç, İngiltere ve ABD’yle yakınlaşması kayda değer gözükmektedir. Nihayetinde Şah Deniz Konsorsiyumu'nca verilen karada Azerbaycan gazının Balkan ülkeleri başta olmak üzere Avrupa piyasalarına ulaştırılmasında NABUCCO yerine nihai tercih TANAP ve TAP doğal gaz boru hattı projeleri olmuştur. TANAP ve TAP'ın geçeceği rota ve proje şirketlerinin hisse yapıları dikkate alındığında AB 'Güney Gaz Koridoru' kavramında AB dışı aktörlerin etkinlik kazanması son derece ilginçtir. Dahası Rusya Federasyonu tarafından geliştirilen Güney Akım projesi de halen masada kalmayı başarmış ve işlerlik kazanma yolunda önemli mesafe kat etmiştir. AB-Rusya-Türkiye arasındaki bu üçayaklı enerji diplomasisi sürecinde, gelecekte projeleri somut olarak gerçekleştirip başarıya ulaşacak olan tarafin belirlenmesinde TAP ve Güney Akım projelerinin rotaların geliştirilip-uzatılmasından, inşaat sürecine kadar birçok yeni etmen devreye girecekken bu yarışın şimdilik açık kaybedeni NABUCCO projesi ile Avusturya özelinde merkezi AB ülkeleri olmuştur.

\section{Kaynakça}

Aleksiyev, A. \& I. Vasiliev (2013), Nabucco West: A Fateful Choice for Bulgaria, $<$ http://www.naturalgaseurope.com/nabucco-west-bulgaria>, 29.06.2013.

Andres, R.B. \& M. Kofman (2011), European Energy Security: Reducing Volatility of UkraineRussia Natural Gas Pricing Disputes, <http://www.ndu.edu/inss/docuploaded/SF\%20264\%20Andres_Kofman.pdf〉, 02.04.2014. 
Barroso, J. (2009), President of the European Commission, Signature of the Nabucco Intergovernmental Agreement, Ankara, 13.07.2009, <http://europa.eu/rapid/pressReleasesAction.do?reference=SPEECH/09/339>, 13.01.2013.

Geropoulos, K. (2013), Gazprom Snubs EU-Ukraine Gas Talks, <http://www.neurope.eu/article/gazprom-snubs-eu-ukraine-gas-talks>, 27.05.2013.

Hacaloğlu, N. (2011), “Putin: Türkiye'nin Güney Akım'a vize vermesi yeni yıl hediyesi”, Hürriyet, 29.12.2011.

Hava, E. (2012), “Out of Nabucco Turkey hopes for brighter future with TANAP”, Today's Zaman, 27.06.2012.

Jukov, S.V. \& et al. (2010), Globalizatsiya rinka prirodnogo gaza: Vozmojnosti i vizovi dlya Rossii, [Doğal gaz piyasasının küreselleşmesi: Rusya için tehdit ve firsatlar], Moskova: IMEMO RAN.

Kaveşnikov, N.Y. (2009), “ 'Rol’ energodialoga Rossiya-EC v obespeçenii energetiçeskoy bezopasnosti ‘Bolşoy Evropı' ’, [Büyük Avrupa'nın enerji güvenliğinin sağlanmasında Rusya-AB enerji diyaloğunun rolü], Vsya Evropa, 33(5).

Kolesnikov, A. (2012), “Turtsiya razvernula pered Vlademirom Putinom svoi kompleksi”, [Türkiye Vlademir Putin'in önünde komplekslerini sergiledi], Kommersant, 04.12.2012.

Komcherkin, M. (2011), “Azerbaydjanskiy gaz uhodit iz pod kontrolya Rossii”, [Azerbaycan gazı Rusya'nın kontrolü altından çıkıyor], RBC Daily, 01.11.2011.

Mamedov, S. (2013), “Azerbaydjan polucit evropeyskiy bonus”, [Azerbaycan Avrupa bonusu alacak], Nezavisimaya Gazeta, 18-06-2013.

Milov, V. (2007), “Energo Dialog Rossiya-EC: Zapolnit' Vakuum,” [Rusya-AB Enerji Diyaloğu: Boşluğu Doldurmak], Rossiya v Global'noy Politike, 5(5).

Özdemir, Volkan (2007), "The Blue Stream Natural Gas Pipeline: Implications on Energy Security and Foreign Policy", Journal of Central Asian \& Caucasian Studies, 2 (3).

Özdemir, Volkan (2014), "Turkey aims to increase regional influence with gas and pipeline deal", Worldreview, <http://www.worldreview.info/content/turkey-aims-increase-regionalinfluence-gas-and-pipeline-deal>, 26.06.2014.

Pavlovska, N. (2010), "Energy Diversification and Market Integration: Means for Achieving Secure Energy Supply in the Western Balkans", Analytical, 3(2).

Pesut, Damir (2013), "Overview of Energy Sector in Balkan Region”, Sunum, <http://siteresources.worldbank.org/EXTENERGY2/Resources/41141991306178323340/S1_Pesut.pdf>, 01.10.2013.

Pop, V. (2011), "Russia lobbies EU for special treatment on pipeline”, EUobserver, 26.05.2011.

Ralchev, S. (2012), Energy in the Western Balkans: A Strategic Overview, Institute for Regional and International Studies.

Rettman, A. (2013), "Russia to cut Ukraine, EU gas in next few days, expert predicts" EUobserver, 28.01.2013. 
Seliverstov, S.S. (2006), "Voprosi Obespeceniya nadejnosti postavok energonositeley v sfere truboprovodnogo transporta EC", [AB'nin boru hattı taşımacılığı alanında enerji kaynaklarının tedarik güvenliğinin sağlanmasına yönelik sorunlar], Moskovskiy Jurnal Mejdunarodnogo Prava, (Spetsialniy Vipusk).

Stambolis, C. (2012), "Redefining SE Europe’s Energy Map - Polıcy Implications”, <http://www.cnrcme.ro/foren2012/PPT/POLICY_TRILEMMA/COSTIS\%20STAMBOLIS.pdf>, 09.03.2013.

Taghiyeva, A. (2013), “Turkey receives proposal to become TAP partner”, Trend Azerbaijan, 28.06.2013.

Yazar, Y. (2010), “Türkiye'nin Enerjideki Durumu ve Geleceği”, <http://arsiv.setav.org/ups/dosya/58085.pdf>, 31.12.2012.

Xuetang, G. (2006), “The Energy Security in Central Eurasia: the Geopolitical Implications to China's Energy Strategy”, The China and Eurasia Forum Quarterly, 4 (4).

\section{Diğer Kaynaklar}

“Nabucco'da proje destek anlasmasi imzalandi”, Haberturk, 08.06.2011.

Açık Oturum, 04.03.2009, Brüksel, European Policy Centre, “Turkey as an energy hub for Europe: prospects and challenges", <http://epc.eu/prog_details.php?cat_id=6\&pub_id=987\&prog_id=1>, 06.05.2013.

“Rusya'ya feri hattı ticareti coşturacak", Milliyet, 20.02.2013.

"Turkey open to hold new Russian oil talks", Hurriyet daily news, 09.04.2011.

"Nabucco gas pipeline must shrink or die", Reuters, 26.04.2012.

B92 (2013), Russia and Macedonia sign south stream offshot deal, $<$ http://www.b92.net/eng/news/region.php?yyyy=2013\&mm=07\&dd=24\&nav_id=87050 $>$, 08.09.2014.

"Balkan states back Tap, IAP gas pipeline projects", Reuters, 23.05.2013, $<$ http://www.reuters.com/article/2013/05/23/gas-balkans-albaniaidUSL6N0E43YR20130523>, 01.06.2013.

“Bp, Statoil, Total Enter TANAP”, 08.11.2012, <http://www.naturalgaseurope.com/bp-statoil-andtotal-take-tanap-stake>.

BP (2013), Statistical Review of World Energy, BP Company, Londra.

Commission of the European Communities (2008), Second Strategic energy Review: An EU Energy Security and Solidarity Action Plan, Brüksel, 02.05.2013.

CSIS-EKEM Policy Report (2010), Re-linking the Western Balkans: The Energy Dimension, <www.csis.org>, 05.09.2014.

Energeticheskaya strategiya Rossii na period do 2030 goda, rasporjenie Pravitelstvo Rossiskoy Federatsii, 1715-p/ 13-11-2009, [Rusya'nın 2030 y1lına kadar Enerji Stratejisi, Rusya Federasyonu Hükümeti 1715 sayılı ve 13 Kasım 2009 tarihli genelgesi]. 
Gazprom (2013), South Stream Pipeline,

<http://www.gazprom.com/about/production/projects/pipelines/south-stream/>,

13.12.2013.

Oilprice (2012), South Stream and the EU-Russia Balance of Power in the Western Balkans, 01.04.2012.

International Gas Union (2013), Wholesale Gas Price Survey, Oslo.

"Rosneft Completes Offshore Projects Deals with Eni and Statoil", RIA Novosti, 21.06.2013.

Statoil (2013), <http://www.statoil.com/en/NewsAndMedia/News/2012/Pages/30aug_Rosneft.aspx>, 07.06.2013.

Trans-Adriatic Pipeline (TAP) (2014), <http://www.trans-adriatic-pipeline.com/tap-project/route/>, 03.04.2014.

Ek Tablo: 1

Avrupa Pazarına Yönelik Doğal Gaz Boru Hattı Projeleri

\begin{tabular}{|c|c|c|}
\hline PROJE & TANAP & GÜNEY AKIM \\
\hline PROJE ŞİRKETÍ & Trans Anatolian Gas Pipeline Company B.V & South Stream Transport AG \\
\hline YATIRIM BEDELI & 9 milyar Euro & 25 Milyar Euro \\
\hline ORTAK ÜLKELER & $\begin{array}{l}\text { Azerbaycan } \\
\text { Türkiye } \\
\text { İngiltere }\end{array}$ & $\begin{array}{l}\text { Rusya Federasyonu } \\
\text { Bulgaristan } \\
\text { Surbistan } \\
\text { Karadağ } \\
\text { Bosna Hersek } \\
\text { Macaristan } \\
\text { Slovenya } \\
\text { İtalya }\end{array}$ \\
\hline GÜZERGÂH & Türkiye & $\begin{array}{l}\text { Rusya-> Bulgaristan -> Sirbistan - } \\
\text { Karadağ- Bosna Hersek> Macaristan -> } \\
\text { Slovenya -> İtalya }\end{array}$ \\
\hline $\begin{array}{l}\text { ORTAK ŞİRKETLER } \\
\text { VE PAYLARI }\end{array}$ & $\begin{array}{l}\text { SOCAR }(\% 58) \\
\text { BOTAŞ }(\% 30) \\
\text { BP }(\% 12)\end{array}$ & $\begin{array}{l}\text { GAZPROM (\%50) } \\
\text { ENI }(\% 20) \\
\text { EDF }(\% 15) \\
\text { WINTERSHALL }(\% 15)\end{array}$ \\
\hline $\begin{array}{l}\text { PLANLANAN } \\
\text { TARİH }\end{array}$ & 2018 & 2016 \\
\hline UZUNLUK & $1800 \mathrm{~km}$ & $\begin{array}{l}925 \mathrm{~km} \text { (Karadeniz) } \\
\text { (Toplam: } 2,400 \mathrm{~km})\end{array}$ \\
\hline KAPASİTE & $\begin{array}{l}16 \text {-> } 23 \text {-> } 31 \text { milyar m3/y1l } \\
(2018 \text {-> } 2023 \text {-> 2026) }\end{array}$ & 63 milyar m3/y1l \\
\hline
\end{tabular}




\section{Ek Tablo 2:}

\section{Avrupa Pazarına Yönelik Doğal Gaz Boru Hattı Projeleri}

\begin{tabular}{|c|c|c|}
\hline PROJE & NABUCCO West & TAP \\
\hline PROJE ŞİRKETİ & NABUCCO International Company (NIC) & Trans Adriatic Pipeline AG \\
\hline $\begin{array}{l}\text { YATIRIM } \\
\text { BEDELI }\end{array}$ & 3 Milyar Euro & 4 Milyar Euro \\
\hline $\begin{array}{l}\text { ORTAK } \\
\text { ÜLKELER }\end{array}$ & $\begin{array}{l}\text { Türkiye } \\
\text { Bulgaristan } \\
\text { Romanya } \\
\text { Macaristan } \\
\text { Avusturya }\end{array}$ & $\begin{array}{l}\text { İsviçre } \\
\text { Norveç } \\
\text { İspanya } \\
\text { Azerbaycan } \\
\text { İngiltere } \\
\text { Belçika }\end{array}$ \\
\hline GÜZERGÂH & Bulgaristan -> Romanya -> Macaristan -> Avusturya & $\begin{array}{l}\text { Yunanistan-> Arnavutluk -> } \\
\text { İtalya - İyonya Gaz Boru } \\
\text { Hattı'na (Hırvatistan- } \\
\text { Karadağ-Bosna-Hersek) } \\
\text { Eklenebilir }\end{array}$ \\
\hline $\begin{array}{l}\text { ORTAK } \\
\text { ŞİRKETLER VE } \\
\text { PAYLARI }\end{array}$ & $\begin{array}{l}\text { OMV (\%34.76) } \\
\text { BOTAŞ }(\% 17.38) \\
\text { Bulgarian Energy Holding }(\% 17.38) \\
\text { FGSZ }(\% 13.1) \\
\text { TRANSGAZ }(\% 17.38) \\
\text { (Hattın seçimi sonrası yapılacak düzenlemeyle Şah Deniz } \\
\text { Konsorsiyumu \%50 pay alacaktı) }\end{array}$ & $\begin{array}{l}\text { BP }(\% 20) \\
\text { SOCAR }(\% 20) \\
\text { STATOIL }(\% 20) \\
\text { FLUXY }(\% 19) \\
\text { ENEGAS }(\% 16) \\
\text { AXPO }(\% 5)\end{array}$ \\
\hline $\begin{array}{l}\text { PLANLANAN } \\
\text { TARİH }\end{array}$ & $2017-2018$ & 2019 \\
\hline UZUNLUK & $1311 \mathrm{~km}$ & $\begin{array}{l}115 \mathrm{~km} \text { (Adriyatik Denizi) } \\
\text { (Toplam: } 520 \mathrm{~km} \text { ) }\end{array}$ \\
\hline KAPASİTE & 10-23 milyar m3/y1l & $\begin{array}{l}10->20 \text { milyar m3/y1l } \\
(2019 \text {-> 2023) }\end{array}$ \\
\hline
\end{tabular}

